\title{
Peranan kadar nitrit oksida (NO) darah dan asupan lemak pada pasien hipertensi dan tidak hipertensi
}

The role levels of blood nitric oxide (NO) and fat intake in patients with hypertension and non hypertension

Pudji Astutik ${ }^{1}$, Bambang Wirjatmadi², Merryana Adriani²

\begin{abstract}
Background: Hypertension is closely related to impaired endothelial dependent vasodilation due to decreasing availability of blood nitric oxide (NO) and high fat intake. Objective: To analyze blood NO and fat intake differences in patients with hypertension and non hypertension. Method: The study was a cross-sectional design and sampling was carried out in Sidoarjo District Hospital. Subjects of the study were 24 patients aged between 40 to 65 years, which consist of 12 cases and 12 controls. Measurement of blood NO and recall of fat intake were performed. Results: Blood NO in hypertension and non hypertension patients were 72.333 $\pm 40.511 \mu \mathrm{M}$ and $116.083 \pm 46.962 \mu \mathrm{M}$ respectively. Fat consumption in hypertension and non hypertension were $51.52 \pm 5.99 \mathrm{~g}$ and $41.65 \pm 8.32 \mathrm{~g}$ respectively. Two independent samples t-test showed meaningful differences in the levels of blood $N O(p=0.023)$ as well as fat intake $(p=0.004)$ between the hypertension and non hypertension patients. Conclusion: There is a difference in the levels of blood NO and fat intake in patients with hypertension and non hypertension.
\end{abstract}

KEY WORDS: hypertension, nitric oxide, fat consumption level

\begin{abstract}
ABSTRAK
Latar belakang: Hipertensi erat kaitannya dengan gangguan vasodilatasi yang tergantung endotel pembuluh darah karena adanya penurunan ketersediaan nitrit oksida (NO) dan asupan tinggi lemak. Tujuan: Menganalisis perbedaan kadar NO darah dan asupan lemak pada pasien hipertensi dan tidak hipertensi. Metode: Penelitian ini merupakan penelitian cross-sectional yang dilakukan di Instalasi Rawat Jalan Rumah Sakit Umum Daerah Kabupaten Sidoarjo. Jumlah sampelnya diambil secara acak sebesar 24 pasien dengan umur 40-65 tahun, terdiri dari 12 kasus hipertensi dan 12 kontrol. Dilakukan pengukuran kadar NO darah dan recall asupan lemak. Hasil: Rerata kadar NO subjek hipertensi sebesar 72,333 $\pm 40,511 \mu \mathrm{M}$ dan tidak hipertensi sebesar 116,083 $\pm 46,962 \mu \mathrm{M}$. Terdapat perbedaan yang bermakna pada kadar $\mathrm{NO}$ antara kelompok subjek hipertensi dan tidak hipertensi berdasarkan uji $t$ dua sampel bebas $(\mathrm{p}=0,023)$. Rerata konsumsi lemak kelompok hipertensi sebesar $51,52 \pm 6,74 \mathrm{~g}$ sedangkan kelompok tidak hipertensi $41,65 \pm 8,32 \mathrm{~g}$. Berdasarkan hasil uji t dua sampel bebas diperoleh perbedaan yang bermakna pada asupan lemak antara kelompok subjek hipertensi dan tidak hipertensi $(\mathrm{p}=0,004)$. Simpulan: Ada perbedaan kadar NO dan asupan lemak pada pasien hipertensi dan tidak hipertensi.
\end{abstract}

KATA KUNCI: hipertensi, nitrit oksida, tingkat konsumsi lemak

\section{PENDAHULUAN}

Kasus penyakit tidak menular diperkirakan akan meningkat menjadi $73 \%$ sebagai penyebab kematian pada tahun 2020 dan merupakan $60 \%$ beban penyakit dunia. World Health Organization - South East Regional Office (WHO-SEARO) termasuk Indonesia, Thailand, Myanmar serta berbagai negara Asia Selatan melaporkan bahwa 52\% penyebab kematian di tahun 2000 adalah penyakit tidak menular, 9\% akibat kecelakaan, dan 39\% akibat penyakit menular serta penyakit lainnya. Salah satu penyakit tidak menular tersebut adalah hipertensi (1). Berdasarkan data The National Health and Examination Survey (NHANES) tahun $1999-2000$, insiden hipertensi pada orang dewasa adalah sekitar $29-31 \%$. Artinya, terdapat 58-65 juta penderita hipertensi di Amerika dan terjadi peningkatan 15 juta dari data NHANES pada tahun 1988-1991 (2). Prevalensi hipertensi di Indonesia berdasarkan hasil Survei Kesehatan Rumah Tangga (SKRT) tahun 2004 sebesar $21 \%$ dan meningkat menjadi 32,2\% pada tahun 2007 (3). Bahkan, menurut data Kementerian Kesehatan RI tahun 2010 menunjukkan bahwa prevalensi hipertensi di Indonesia meningkat menjadi $34,1 \%$ (4).

${ }^{1}$ Korespondensi: Program Magister Fakultas Kesehatan Masyarakat Universitas Airlangga Surabaya, Kampus C Mulyorejo 60115, e-mail: pudjiastutik51@ yahoo.com

2 Fakultas Kesehatan Masyarakat Universitas Airlangga Surabaya, Kampus C Mulyorejo 60115,e-mail: anna_b_wirjatmadi@yahoo.com 
Penyakit hipertensi merupakan masalah yang besar dan serius. Selain karena prevalensinya yang tinggi dan cenderung meningkat di masa datang, dampak tingkat keganasan penyakit juga sangat berbahaya seperti penyakit jantung, stroke, gagal ginjal, dan lain sebagainya, bahkan dapat menimbulkan kecacatan permanen dan kematian mendadak. Penyakit hipertensi pada kelompok dewasa muda akan sangat membebani perekonomian keluarga karena biaya pengobatan yang mahal dalam jangka waktu yang panjang, bahkan seumur hidup (5).

Beberapa penelitian menunjukkan bahwa gangguan vasodilatasi yang tergantung endotel terjadi pada penderita hipertensi karena fungsi endotel berhubungan dengan bioaktivitas dari nitrit oksida (NO) yang tergantung interaksinya dengan reactive oxygen species (ROS) khususnya superoksida. Reaksi NO dengan superoksida akan menghasilkan peroksinitrit (ONOO-) yang merupakan reaktif nitrogen spesies. Peroksinitrit ini akan mengoksidasi pteridin tetrahydrobiopterin (BH4) yang merupakan kofaktor untuk nitric oxide synthase (NOS). Kondisi ini mengakibatkan NOS menghasilkan superoksida daripada NO sehingga sintesis NO menurun. Penurunan kadar NO menyebabkan proses relaksasi endotel terganggu sehingga berakibat terjadinya hipertensi (6).

Selain itu, terjadinya hipertensi bisa juga dipengaruhi oleh faktor makanan. Besarnya volume makanan dengan kandungan lemak tinggi, memberikan energi lebih tinggi sehingga menjadi kendala dalam mengatur keseimbangan energi. Kecenderungan perilaku makan tinggi lemak akan mengakibatkan ketidakseimbangan lemak yang akan disimpan dalam jaringan adiposa dan pada akhirnya terjadi penimbunan jaringan lemak di dalam tubuh (7). Selain sebagai tempat penyimpanan energi, jaringan lemak juga menghasilkan faktor yang menyebabkan hipertensi yaitu dengan menguraikan angiotensin dari sistem angiotensin-renin (8). Asupan lemak yang berlebihan akan menginduksi aktifasi sel endotel vaskuler, yang pada gilirannya dapat mengakibatkan disfungsi endotel dan produksi ROS, penurunan produksi NO dan oksidasi low density lipoprotein (LDL) melalui peningkatan substrat, perubahan konformasi LDL yang lebih rentan terhadap oksidasi, serta peningkatan produksi radikal superoksida (O2-) vaskuler (9).
Apabila terdapat lemak yang memiliki Apo-B 100 yaitu very low density lipoprotein (VLDL) dan LDL dalam jumlah banyak dan dalam waktu yang lama, maka dapat menimbulkan deposisi kolesterol dan ester kolesteril pada jaringan ikat dinding pembuluh arteri. Jaringan otot halus dan jaringan fibrosa di sekitarnya akan berproliferasi membentuk plak. Dengan berjalannya waktu, plak akan bertambah besar. Plak yang bertambah besar ditambah dengan garam kalsium yang ikut mengendap akan mengakibatkan terjadinya aterosklerosis yang merupakan salah satu penyebab terjadinya hipertensi (10). Penelitian ini bertujuan untuk mengetahui perbedaan kadar NO darah dan tingkat asupan lemak pada pasien hipertensi dan tidak hipertensi.

\section{BAHAN DAN METODE}

Rancangan penelitian ini adalah cross-sectional yang dilaksanakan pada bulan Maret - April 2013 di Instalasi Rawat Jalan Rumah Sakit Umum Daerah (RSUD) Kabupaten Sidoarjo. Populasi penelitian adalah semua pasien yang berobat di Instalasi Rawat Jalan RSUD Sidoarjo dan berusia 40-65 tahun. Sampel penelitian adalah bagian dari populasi yang telah diperiksa tekanan darahnya, kemudian dibagi menjadi dua kelompok yaitu hipertensi (kasus) dan tidak hipertensi (kontrol). Kriteria inklusi kelompok kasus adalah pasien yang menderita hipertensi primer dan belum ada komplikasi penyakit lain sedangkan kriteria inklusi kelompok kontrol adalah pasien tidak menderita hipertensi dan komplikasi penyakit lain (diabetes mellitus, gangguan ginjal, gangguan jantung, stroke). Besar sampel diperoleh menggunakan rumus (11) dengan tingkat kemaknaan $\alpha$ $=0,05$ dan $\beta=0,10$; standar deviasi $(\sigma)$ hipertensi dalam penelitian sebelumnya sebesar 0,6 ; dan selisih rata-rata minimal yang dianggap bermakna $(\delta)$ sebesar 0,5 maka didapatkan besar sampel penelitian sebanyak 12 pasien untuk setiap kelompok. Subjek penelitian kemudian dibedakan menjadi dua kelompok, 12 pasien hipertensi dan 12 pasien tidak hipertensi yang telah dilakukan matching terhadap umur dan jenis kelamin.

Definisi hipertensi dalam penelitian ini berdasarkan The Seventh Report of the Joint National Commitee on Prevention of High Blood Pressure (JNC VII). Seseorang dikatakan hipertensi apabila tekanan darah diastolik lebih 
dari atau sama dengan $90 \mathrm{mmHg}$ dan atau sistolik lebih dari atau sama dengan $140 \mathrm{mmHg}$. Pengambilan bahan pemeriksaan (darah) dari vena cubiti sampel sebanyak 5 ml diukur secara Colorimetrik Non-Enzymatic Nitric Oxide Assay dan menggunakan kit dari biomedical research and development product (R\&D) dengan prinsip kerja yaitu mengukur kadar nitrit yang merupakan hasil degradasi NO yang bersifat stabil secara spektrofotometri pada panjang gelombang $540 \mathrm{~nm}$. Nitrat yang juga merupakan hasil degradasi NO akan diubah terlebih dahulu menjadi nitrit dengan bantuan logam kadmium (Cd). Pemeriksaan kadar NO dilakukan di Laboratorium Biomedik Universitas Brawijaya oleh petugas laboran sedangkan pemeriksaan tekanan darah dilakukan oleh perawat jaga.

Pengukuran tingkat konsumsi lemak dilakukan oleh peneliti yang diperoleh dari recall 1×24 jam karena peneliti sudah melakukan studi pendahuluan yang hasilnya bahwa sampel memiliki jenis konsumsi lemak yang relatif homogen. Hal tersebut disebabkan oleh sampel yang tinggal di daerah homogen (perkotaan) sehingga tidak perlu dilakukan recall lebih dari 2x24 jam. Recall tersebut kemudian dikonversi ke dalam satuan gram (g) dengan menggunakan daftar komposisi bahan makanan (DKBM) dan selanjutnya dibandingkan dengan angka kecukupan gizi (AKG). Perhitungan indeks massa tubuh (IMT) dilakukan peneliti dengan mengukur tinggi badan dan berat badan.

Hipotesis penelitian ini adalah ada perbedaan kadar NO dan tingkat asupan lemak antara pasien hipertensi dan tidak hipertensi. Hipotesis tersebut dianalisis secara statistik untuk menghitung nilai rerata (mean) dan standar deviasi (SD) dari kadar NO dan tingkat asupan lemak pada setiap kelompok. Uji beda dilakukan menggunakan uji $\mathrm{t}(\mathrm{p}<0,05)$ untuk mencari ada tidaknya perbedaan antara kadar NO dan tingkat asupan lemak pada pasien hipertensi dan tidak hipertensi. Penelitian ini sudah disetujui Komite Etik Fakultas Kesehatan Masyarakat Universitas Airlangga Surabaya dengan nomor 53 - KEPK.

\section{HASIL}

\section{Karakteristik subjek}

Berdasarkan hasil penelitian diperoleh rerata usia kelompok kontrol adalah 46,08 $\pm 52,58$ tahun dengan usia terendah 41 tahun dan tertinggi 54 tahun sedangkan
Tabel 1. Distribusi karakteristik subjek berdasarkan usia dan jenis kelamin

\begin{tabular}{lcccc}
\hline \multirow{2}{*}{ Variabel } & \multicolumn{2}{c}{ Kontrol } & \multicolumn{2}{c}{ Kasus } \\
\cline { 2 - 5 } & $\mathbf{n}$ & $\mathbf{\%}$ & $\mathbf{n}$ & $\mathbf{\%}$ \\
\hline Jenis kelamin & & & & \\
$\quad$ Laki-laki & 3 & 25 & 4 & 33 \\
Perempuan & 9 & 75 & 8 & 67 \\
$\quad$ Total & 12 & 100 & 12 & 100 \\
Usia (tahun) & & & & \\
40-45 & 6 & 50 & 1 & 8 \\
$46-50$ & 4 & 33 & 3 & 25 \\
$51-55$ & 2 & 17 & 5 & 42 \\
$56-60$ & 0 & 0 & 3 & 25 \\
Total & 12 & 100 & 12 & 100 \\
\hline
\end{tabular}

rerata usia kelompok kasus $52,58 \pm 4,85$ tahun dengan usia terendah 43 tahun dan tertinggi 60 tahun. Subjek wanita lebih banyak pada kedua kelompok (kontrol $75 \%$, kasus 67\%) (Tabel 1).

Berdasarkan Tabel 2 menunjukkan bahwa rerata IMT kelompok kontrol sebesar $24,3 \pm 2,4 \mathrm{~kg} / \mathrm{m}^{2}$ sedangkan kelompok kasus sebesar $26,8 \pm 4,1 \mathrm{~kg} / \mathrm{m}^{2}$. Rerata tekanan darah sistolik pada kelompok kontrol 116,7 $\pm 12,3 \mathrm{mmHg}$ dan tekanan darah diastolik $76,7 \pm 4,9 \mathrm{mmHg}$ sedangkan rerata tekanan darah sistolik pada kelompok kasus

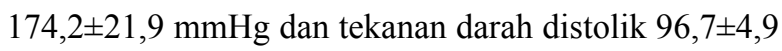
$\mathrm{mmHg}$. Pada kelompok kontrol yang mengalami obesitas sebesar $25 \%$ sedangkan kelompok kasus sebesar $50 \%$. Hasil tersebut menunjukkan bahwa subjek yang obesitas lebih banyak ditemukan pada kelompok hipertensi dibandingkan yang tidak hipertensi.

\section{Kadar nitrit oksida (NO)}

Nitrit oksida merupakan senyawa yang dapat menyampaikan sinyal terhadap otot polos dalam lapisan pembuluh darah untuk berelaksasi sehingga menyebabkan pelebaran pembuluh darah (vasodilatasi) yang berdampak pada penurunan darah. Tabel 3 menunjukkan bahwa rerata kadar NO pada kelompok kontrol sebesar 116,1 $\pm 46,9$ $\mu \mathrm{M}$ sedangkan pada kelompok kasus $72,3 \pm 40,6 \mu \mathrm{M}$. Hasil uji perbedaan menggunakan uji t dua sampel bebas menunjukkan ada perbedaan yang signifikan antara kadar NO kelompok kontrol dan kelompok kasus $(\mathrm{p}=0,023)$. Pada kelompok kasus (hipertensi) lebih cenderung memiliki kadar NO yang lebih rendah dibandingkan kelompok kontrol (tidak hipertensi). 
Pudji Astutik, dkk: Peranan kadar nitrit oksida (NO) darah dan asupan lemak pada pasien hipertensi dan tidak hipertensi

Tabel 2. Distribusi IMT dan tekanan darah pada kelompok kasus dan kontrol

\begin{tabular}{|c|c|c|c|c|c|c|c|c|}
\hline \multirow{2}{*}{ Variabel } & \multicolumn{3}{|c|}{ Kontrol } & \multicolumn{3}{|c|}{ Kasus } & \multirow{2}{*}{$\mathbf{t}$} & \multirow{2}{*}{$\mathbf{p}$} \\
\hline & Rerata \pm SD & Min & Maks & Rerata \pm SD & Min & Maks & & \\
\hline IMT $\left(\mathrm{kg} / \mathrm{m}^{2}\right)$ & $24,3 \pm 2,4$ & 20,9 & 28 & $26,8 \pm 4,1$ & 19,8 & 34,7 & $-3,27$ & 0,033 \\
\hline \multicolumn{9}{|c|}{ Tekanan darah $(\mathrm{mmHg})$} \\
\hline Sistolik & $116,7 \pm 12,3$ & 100 & 130 & $174,2 \pm 21,9$ & 150 & 210 & 2,37 & 0,039 \\
\hline Diastolik & $76,7 \pm 4,9$ & 70 & 80 & $96,7 \pm 4,9$ & 90 & 100 & 2,56 & 0,028 \\
\hline
\end{tabular}

Tabel 3. Distribusi kadar NO dan asupan lemak pada kelompok kasus dan kontrol

\begin{tabular}{lcccccccc}
\hline \multirow{2}{*}{ Variabel } & \multicolumn{3}{c}{ Kontrol } & \multicolumn{3}{c}{ Kasus } & \multirow{2}{*}{ t } & \multirow{2}{*}{} \\
\cline { 2 - 8 } & Rerata \pm SD & Min & Maks & Rerata \pm SD & Min & Maks & & \\
\hline Kadar NO $(\mu \mathrm{M})$ & $116,1 \pm 46,9$ & 71,0 & 205,7 & $72,3 \pm 40,6$ & 24,3 & 151,7 & 2,4 & 0,023 \\
Asupan lemak $(\mathrm{g})$ & $41,7 \pm 8,3$ & 27,7 & 54,6 & $51,5 \pm 6,7$ & 43,3 & 61,9 & $-3,17$ & 0,004 \\
\hline
\end{tabular}

\section{Asupan lemak}

Proporsi lemak yang diangap baik pada masa dewasa adalah kurang dari 30\% dari total energi. Tabel 3 menunjukkan bahwa rerata asupan lemak pada kelompok

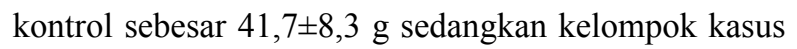
$51,5 \pm 6,7 \mathrm{~g}$. Hasil uji perbedaan menggunakan uji $\mathrm{t}$ dua sampel bebas ditemukan ada perbedaan yang signifikan antara asupan lemak kelompok kontrol dan kelompok kasus ( $\mathrm{p}=0,023$ ). Pada kelompok kontrol lebih cenderung memiliki asupan lemak yang lebih rendah dibandingkan kelompok kasus.

\section{BAHASAN}

Hasil penelitian ini menunjukkan bahwa terdapat perbedaan yang bermakna kadar NO darah pada subjek dengan hipertensi dan tidak hipertensi. Hal ini sejalan dengan penelitian sebelumnya yang menyatakan bahwa ada perbedaan kadar NO pada pasien hipertensi dan tidak hipertensi (12). Beberapa teori menyebutkan bahwa semakin rendah kadar NO darah, semakin tinggi tekanan darah sistolik dan diastolik karena NO merupakan senyawa yang bersifat vasodilator (13). Semakin parah kerusakan endotel akibat stres oksidatif yang berlebihan, maka produksi NO akan semakin rendah, tekanan darah semakin tinggi, dan hipertensi bertambah berat (14).

Rerata kadar NO darah antara kelompok hipertensi dan tidak hipertensi menunjukkan perbedaan yang bermakna yaitu lebih rendah pada kelompok hipertensi dibandingkan kelompok tidak hipertensi.
Peningkatan produksi superoksida dapat mendegradasi NO untuk menurunkan sintesis NO. Degradasi NO akan menyebabkan disfungsi vasomotor, aktivasi endotel yang mengekpresikan molekul adhesi, proliferasi otot polos menginduksi, ekspresi gen inflamasi, menginduksi apoptosis, migrasi, dan reorganisasi matrik seluler yang dapat mengganggu vasorelaksasi yang tergantung endotel. Hal ini merupakan mekanisme yang mengawali terjadinya hipertensi (15).

Nitrit oksida yang juga dikenal sebagai nitrogen monoksida merupakan zat perantara yang sangat penting dalam siklus kimia di dalam tubuh. Pada manusia, senyawa NO merupakan senyawa kimia yang penting untuk tranportasi sinyal listrik di dalam sel-sel dan berfungsi dalam proses fisiologis dan patologis. Selain itu, senyawa ini bisa menyebabkan pelebaran pembuluh darah atau dalam istilah kedokteran disebut vasodilator yang kuat sehingga bisa menurunkan tekanan darah (14). Nitrit oksida juga berperan terhadap regulasi dan pemeliharaan tekanan pembuluh darah. Nitrit oksida dihasilkan sel endotel dan memiliki efek vasodilatasi dan antiproliferasi pada sel otot polos vaskular. Pelepasan NO akan memicu terjadinya relaksasi otot polos vaskular. Penurunan NO dapat terjadi akibat adanya penurunan aktivitas enzim NOS. Penurunan aktivitas NOS menyebabkan vasokonstriksi dan hipertensi (13). Beberapa ahli mengatakan reaksi antara superoksida dan NO akan menghasilkan peroksinitrit yang merupakan oksidan potensial yang dapat mengakibatkan disfungsi endotel. Meningkatnya peroksinitrit mengakibatkan NOS lebih banyak menghasilkan superoksida daripada NO, 
penurunan kadar $\mathrm{NO}$ akan menyebabkan relaksasi endotel terganggu yang berakibat terjadinya hipertensi (6).

Hasil uji statistik menunjukkan bahwa terdapat perbedaan tingkat asupan lemak antara subjek hipertensi dan tidak hipertensi $(p=0,004)$. Hal ini sesuai dengan penelitian sebelumnya yang menyatakan subjek dengan hipertensi cenderung mengonsumsi makanan tinggi lemak dibandingkan dengan subjek normal. Asupan tinggi lemak berisiko 4,3 kali untuk mengalami hipertensi $(\mathrm{p}=0,002$; $\mathrm{OR}=4,3 ; \mathrm{CI}=1,696-11,069)$ (16). Makanan tinggi lemak tidak memberi rasa kenyang, tetapi hanya memberikan rasa gurih sehingga menyebabkan volume makanan lebih besar supaya kenyang. Besarnya volume makanan dengan kandungan lemak tinggi, memberikan energi lebih tinggi sehingga menjadi kendala dalam mengatur keseimbangan energi. Kecenderungan perilaku makan yang tinggi lemak akan mengakibatkan ketidakseimbangan lemak yang akan disimpan dalam jaringan adiposa. Peningkatan jaringan adiposa akan meningkatkan leptin sehingga berpengaruh terhadap pengaturan keseimbangan energi yang pada akhirnya dapat menyebabkan obesitas (17). Obesitas dapat menyebabkan sindrom metabolik seperti resistensi insulin, dislipidemia, dan hipertensi. Resistensi insulin yang disertai dengan gangguan fungsi endotel pembuluh darah dapat menyebabkan vasokonstriksi dan reabsorbsi natrium di ginjal yang mengakibatkan hipertensi $(7,18,19)$.

Penelitian sebelumnya menyatakan bahwa kebiasaan sering mengonsumsi lemak jenuh yaitu lebih dari atau sama dengan 3 kali dalam seminggu terbukti sebagai faktor risiko yang berpengaruh terhadap kejadian hipertensi ( $\mathrm{p}=0,024$; OR adjusted $=7,72 ; 95 \% \mathrm{CI}=2,45$ 24,38) (20). Hal ini juga didukung penelitian lain yang menyatakan konsumsi lemak jenuh dapat menyebabkan dislipidemia, sementara dislipidemia merupakan salah satu faktor utama risiko aterosklerosis. Aterosklerosis ini akan meningkatkan resistensi dinding pembuluh darah yang dapat memicu jantung untuk meningkatkan denyutnya, denyut jantung yang meningkat dapat meningkatkan volume aliran darah yang berefek terhadap peningkatan tekanan darah (21).

Kelompok senyawa lemak jenis oksisterol merupakan aktivator bagi liver $X$ receptors (LXR) yang merupakan sensor bagi kolesterol. Saat jumlah oksisterol meningkat, maka LXR akan menjaga sel dari kelebihan kolesterol dengan cara meningkatkan ekskresi kolesterol melalui jalur sintesis asam empedu melalui peningkatan ekspresi dari CYP7A1. Meningkatnya ekspresi CYP7A1 akan meningkatkan aktivitas dari CYP7A1. Meningkatnya aktivitas CYP7A1 akan meningkatkan konsumsi oksigen dan nicotinamide adenine dinucleotide phosphate (NADPH) yang kemudian akan meningkatkan radikal superoksida (O2-) yang dihasilkan. Radikal superoksida yang dihasilkan dalam ekskresi kolesterol akan meningkatkan jumlah radikal bebas di dalam tubuh sehingga tingkat oksidasi di dalam tubuh dapat meningkat. Meningkatnya superoksida akan menurunkan kadar NO, penurunan kadar NO akan menyebabkan relaksasi endotel terganggu yang berakibat terjadinya hipertensi (22).

\section{SIMPULAN}

Kadar NO pada kelompok hipertensi lebih rendah dibandingkan kelompok tidak hipertensi. Sebaliknya, tingkat asupan lemak pada kelompok hipertensi lebih tinggi dibandingkan kelompok tidak hipertensi. Terdapat perbedaan kadar NO dan asupan lemak pada kelompok hipertensi dan tidak hipertensi.

\section{RUJUKAN}

1. Surkesnas. Laporan survei kesehatan rumah tangga (SKRT), studi morbiditas dan disabilitas. Jakarta: Badan Penelitian dan Pengembangan Kesehatan, Departemen Kesehatan; 2004.

2. Yogiantoro M. Hipertensi esensial dalam buku ajar ilmu penyakit dalam jilid I edisi IV. Jakarta: Fakultas Kedokteran Universitas Indonesia; 2006.

3. Badan Penelitian dan Pengembangan. Survei nasional (Surkesnas) 2004: SKRT 2004 - vol 2: status kesehatan masyarakat Indonesia. Jakarta: Badan Penelitian dan Pengembangan Kesehatan; 2005.

4. Kemenkes RI. Profil kesehatan Indonesia 2010. Jakarta: Kemenkes RI; 2011.

5. Yundini. Faktor resiko hipertensi. Jakarta: Warta Pengendalian Penyakit tidak Menular; 2006.

6. Rohman SD. Oxidative stress and cardiovascular injury. Dalam Kumpulan Makalah PIT Nasional IV PDS PATKLIN; 2005 Nov 25-27; Malang.

7. Haris S, Tambunan T. Hipertensi pada sindrom metabolik. Sari Pediatri 2009;11(4):257-63. 
8. Torrance B, McGuire KA, Lewanczuk R, McGavock J. Overweight, physical activity and high blood pressure in children: a review of the literature. Vasc Health Risk Manag 2007;3(1):139-49.

9. Setiati. Buku ajar ilmu penyakit dalam jilid III. Jakarta: Pusat Penerbitan Departemen Ilmu Penyakit Dalam Fakultas Kedokteran Universitas Indonesia; 2006.

10. Hartanto. Patofisiologis: konsep klinis proses-proses penyakit edisi 6. Jakarta: EGC; 2005.

11. Kuntoro. Metode sampling dan penentuan besar sampel. Surabaya: Pustaka Melati; 2010.

12. Slamet S, Rossa E. Peran F2-isoprostan dan nitrik oksida sebagai penanda stres oksidatif dan disfungsi endotel pada penderita preeklamsi. Jurnal Kesehatan Masyarakat 2007;7(1):47-54.

13. Tyagi N, Sedoris KC, Steed M, Ovechkin AV, Moshal KS, Tyagi SC. Mechanisms of homocysteine induced oxidative stress. Am J Physiol Heart Circ Physiol 2005;289(6):264956.

14. Ikrar T. Nitric oxide berperan dalam pencegahan dan penyembuhan penyakit jantung dan pembuluh darah. [series online] 2012 [cited 2013 Jan 7]. Available from: URL: http.//kabarinews.com/nitric-oxide-berperan-dalampencegahan-dan-penyembuhan-penyakit-jantung-danpembuluh-darah/49513
15. Taniyama Y, Griendling KK. Reactive oxygen species in the vasculature: molecular and cellular mechanisms. Hypertension 2003;42(6):1075-81.

16. Martalina KT, Sulchan M. Hight fat intake and sport activity as risk factors of obesity hypertension in early adolescence. Journal of Nutrition Collage 2012;1:169-78.

17. Wang Y,Lobstein T. Worldwife trends in childood overweight on obesity. Int J Pediatr Obes 2006;1(1):11-25.

18. Chao CL, Kuo TL, Lee YT. Effect of methionineinduced hyperhomosistein on endothelium-dependent vasodilatation and oxidative status in healthy adults. Circulation 2010;101(5):485-90.

19. Taddei S, Virdis A, Ghiadoni L, Salvetti G, Salvetti A. Endothelial dysfunction in hypertension. J Nephrol 2000;13(3):205-10.

20. Sugiarto A. Faktor-faktor resiko hipertensi grade II pada masyarakat (studi kasus di Kabupaten Karanganyar) [Tesis]. Semarang: Universitas Diponegoro; 2007.

21. Manurung E. Hubungan antara asupan asam lemak tak jenuh tunggal dengan kadar kolestrol HDL plasma penderita penyakit jantung koroner [Tesis]. Jakarta: Program Magister Sains Ilmu Gizi Klinik Universitas Indonesia; 2004.

22. Farketich. Links among depression, race hipertension, and the heart. USA: J. Clins Hypertens 2 (6) Le Jacq Communications; 2005. 